\title{
ENTREVISTA COM ALISON ENTREKIN
}

\author{
Eclair Antonio Almeida Filho ${ }^{1}$ \\ Pedro Henrique Reis $\underline{1}$ \\ ㄴUniversidade de Brasília, Brasília, Distrito Federal, Brasil
}

Alison Entrekin está entre os mais prestigiados tradutores de literatura no par inglês-português no mercado editorial internacional. Traduziu obras dos mais variados autores e estilos, como Perto do Coração Selvagem, de Clarice Lispector, Cidade de Deus, de Paulo Lins, O Filho Eterno, de Cristóvão Tezza e $O$ Doce Veneno do Escorpião, de Bruna Surfistinha. Em 2019, a tradutora foi contemplada com o NSW Premier's Translation Prize, um dos mais importantes prêmios australianos de tradução. Atualmente, Entrekin está sendo patrocinada pela fundação Itaú Cultural para realizar uma nova versão de Grande Sertão: Veredas, obra-prima de João Guimarães Rosa, para a língua inglesa. Pela fundação Itaú Cultural, a tradutora também tem ministrado oficinas de tradução, nas quais discute seu trabalho com o romance de Guimarães de Rosa. Nesta entrevista, concedida no intervalo de uma dessas oficinas, Alison Entrekin responde a perguntas sobre a sua carreira como tradutora e sobre o desafio de traduzir Grande Sertão: Veredas.

Cadernos de Tradução (CT): Como surgiu seu interesse por tradução e, em seguida, por tradução de literatura brasileira?

Alison Entrekin $(A K)$ : Meu interesse em tradução começou aqui no Brasil porque, quando cheguei aqui (eu aprendi somente o básico de português antes de vir) não queria ter problemas com a língua. 
Eu não falava outra língua com fluência, então eu nem sabia se teria facilidade para traduzir. Mas, estando aqui no Brasil percebi que tinha um bom ouvido e que conseguia falar bem o português. Além disso, eu já tinha uma formação em criação literária lá na Austrália e, quando eu comecei a me interessar por tradução, eu queria relacionar essa nova atividade com minha formação original em criação literária: o caminho mais óbvio foi o da tradução literária. Naquela época havia um certo hiato, isto é, passaram-se vários anos em que poucas obras brasileiras tinham sido traduzidas e havia poucas pessoas fazendo a tradução do português brasileiro para o inglês. Naquele tempo, as pessoas me avisavam: "Ninguém ganha o pão com isso, esquece". Eu não dei ouvidos a ninguém e fui trabalhando como tradutora de vários tipos de texto, mas sempre procurando uma entrada no mercado editorial literário.

(CT): Quais teorias, teóricos da tradução e tradutores mais influenciaram seu trabalho? Há brasileiros entre eles?

$(A K)$ : No começo dos anos 2000, eu li na Revista VEJA uma entrevista com o Paulo Henriques Britto, na qual ele falava sobre seu trabalho de tradução e que, numa determinada época, ele tinha feito muitas traduções para o inglês. Eu acho que foi isso que me deu o estalo e eu falei "Nossa! Eu também posso fazer isso, e quero fazer isso!”. E foi a partir daí que comecei a pensar em trabalhar com tradução. Então, em termos de tradutores, com certeza o Paulo Henriques Britto. Eu também sempre li em inglês, antes de vir para o Brasil, autores em tradução, e por mais que eu não falasse as línguas e não tivesse acesso aos originais, eu via o nome do tradutor ali e isso me chamava a atenção, porque eu me perguntava: "Como será que foi feita a tradução, quais foram os caminhos, as dificuldades?". Eu não fazia ideia, mas me despertou o interesse. E, quanto a teorias de tradução, posso dizer que eu li muitos teóricos mais no começo da carreira, quando eu estava estudando, e muitas coisas entraram no meu inconsciente, mas hoje 
eu não sigo nenhuma escola de tradução nem teoria de tradução. É um processo intuitivo. De uns anos para cá, comecei a escrever uma coluna na Revista Pessoa, em que eu discuto as traduções que eu fiz, porque eu queria deixar registrado o porquê das coisas, então eu fui sistematicamente dissecando as traduções de diferentes livros, para deixar registrado o meu processo tradutório. O fato é que eu sempre encontrava problemas e questões que eu não achava nos teóricos de tradução, porque eu achava a teoria em geral mais acadêmica, e muito menos prática, e eu queria escrever sobre as questões práticas que a gente tem de lidar no dia a dia.

(CT): Como morar e viajar pelo Brasil fazem diferença na sua tradução de Grande Sertão Veredas?

$(A K)$ : Morar aqui dá essa familiaridade com o português. Obviamente que esse português do Guimarães Rosa, esse dialeto, ou idioleto, do Riobaldo, não é o normal que eu escuto no dia a dia, mas acho que estar aqui que me dá a mesma proximidade que o leitor brasileiro tem com a língua, e me ajuda a saber o quanto existe estranheza ou não na escrita dele. Viajar é a interessante. Ano passado fui a Cordisburgo. Estar lá onde nasceu Guimarães Rosa e ver algumas coisas ao vivo... talvez não mude nada na forma de traduzir, mas me dá mais dimensão, uma sensação de como é o lugar. Aliás, mais do que ver as coisas, foi ouvir as pessoas, ouvir a forma de falar das pessoas e entender melhor esse dialeto, essas questões regionais.

(CT): Você afirmou, na Oficina de Tradução, que não pretende calcar sua tradução de GSV (Grande Sertão Veredas) no inglês de nenhum país em particular, mas sim que pretende criar um inglês do sertão. $O$ que é esse inglês do sertão e quais são as ferramentas para construí-lo? 
$(A K)$ : Ainda estou descobrindo (risos). Ainda estou construindo. Primeiro, trata-se de evitar qualquer coisa que remeta a algum lugar. É um exercício de restrição. Isso significa achar o meio do caminho, usando um inglês mais universal. Não que eu não use no meio do caminho palavras que são do inglês americano, britânico, australiano etc., mas devem ser bem dosadas, para que o texto não fique muito "carregado". E é possível. Como o próprio Guimarães Rosa cria muitos vocábulos, também é necessário que eu faça a mesma coisa. Se ele vai criando neologismos o tempo todo, eu também vou criando neologismos o tempo todo. O que é mais difícil de recriar é a sintaxe dele, que tem essa oralidade então eu também tento recriar essa oralidade, essa tentativa do Riobaldo de falar bonito, mas sem acertar a mão toda hora, suas redundâncias, suas repetições, sua fala entrecortada. Ele emenda um pensamento no outro. Tudo isso eu tento recriar em inglês, usando recursos próprios da língua inglesa. Um exemplo: em inglês a gente temos phrasal verbs, que o português não tem. Isso, para mim, tem sido uma saída fantástica, porque criar um phrasal verb é muito fácil, basta pegar uma partícula e juntar com um verbo e dar a eles um novo sentido.

(CT): Finalmente, qual é a importância de se fazer uma nova tradução de GSV em 2019?

$(A K)$ : A primeira tradução foi pouco lida. Teve uma primeira impressão, a crítica não foi muito boa, e não foi muito além disso. Sequer venderam todos os exemplares, e nunca teve houve segunda tiragem, o que limitou muito o alcance da obra no universo de língua inglesa. Então somente alguns especialistas em universidades estudam, e trabalham o Grande Sertão com seus alunos, mas é muito restrito. Creio que, por falta de uma boa tradução, o romance ainda não ganhou o lugar que ele merece na literatura mundial. Por isso, é importante fazer uma nova tentativa de colocá-lo nesse lugar. Não é nem uma questão de atualizar a tradução, porque, por ser algo tão inusitado, e por ele já na época em que escreveu o livro ter resolvido 
usar arcaísmos, para criar certos efeitos, não é o caso de se colocar novas gírias e coisas atualizadas no livro. Nada é lugar comum, nada é clichê, nada é do jeito que as pessoas falam normalmente. Então, o problema é uma questão mesmo de fazer uma tradução que dê conta dessa outra dimensão, a dimensão linguística. A primeira tradução só contou a história, não tentou recriar a linguagem de Guimarães Rosa. Essa é a importância de se fazer uma nova tradução.

\section{Referências}

Lins, Paulo. City of God. Tradução de Alison Entrekin. Londres: Bloomsbury, 2006.

Lispector, Clarice. Near to the Wild Heart. Tradução de Alison Entrekin. Londres: Penguin Books, 2014.

Rosa, João Guimarães. Grande Sertão: Veredas. São Paulo: Companhia das Letras, 2018.

Surfistinha, Bruna. The Scorpion's Sweet Venom: the Diary of a Brazilian Call Girl. Tradução de Alison Entrekin. Londres: Bloomsbury, 2007.

Tezza, Cristóvão. The Eternal Son: A Novel. Tradução de Alison Entrekin. Brunswick: Scribe, 2010.

Recebido em: 27/09/2019

Aceito em: 10/12/2019

Publicado em janeiro de 2020

Eclair Antonio Almeida Filho. E-mail: eclair.filho@hotmail.com.

ORCID: https://orcid.org/0000-0002-5098-1017

Pedro Henrique Reis. E-mail: pedro.hc.reis@gmail.com.

ORCID: https://orcid.org/0000-0002-9274-5493 